\title{
O COMÉRCIO ILEGAL DE AFRICANOS NO SUL-FLUMINENSE: OS SOUZA BREVES E SUAS FAZENDAS ${ }^{1}$
}

\author{
AFRICAN ILLICIT TRADE IN SOUTH-FLUMINENSE: \\ THE SOUZA BREVES AND THEIR FARMS;
}

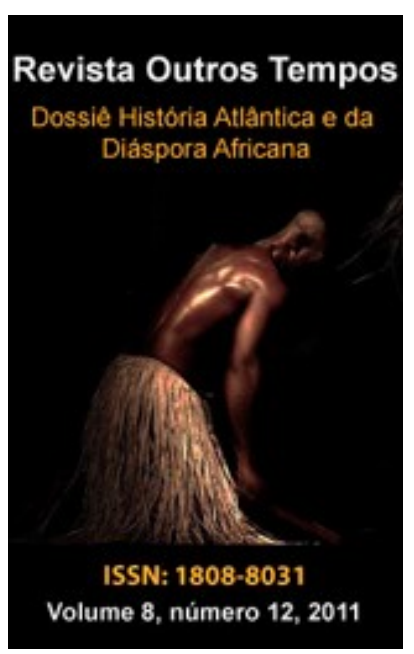

\author{
THIAGO CAMPOS PESSOA \\ Doutorando PPGH-UFF \\ Rio de Janeiro-Brasil \\ tcpessoa@hotmail.com
}

Resumo: O presente artigo analisará o envolvimento de uma das mais ricas famílias do Brasil Império com o tráfico ilegal de africanos. Os irmãos José e Joaquim de Souza Breves, indivíduos de destaque na política e na sociedade brasileira do século XIX, construíram um verdadeiro império territorial e humano, conformado por milhares de escravos, dispostos por suas propriedades. Certamente construíram uma das maiores fortunas de sua época. Do litoral Sul-Fluminense ao Vale do Paraíba, deparamo-nos com dezenas de fazendas, marcadas essencialmente pela presença africana. Buscaremos compreender como a relação dos Comendadores Breves com o comércio ilegal de escravos delineou características singulares às suas propriedades litorâneas, iluminando, no tempo presente, novas questões sobre os últimos anos do tráfico de africanos para o Brasil.

Palavras-chave: Tráfico ilegal de africanos. Escravidão. Família Breves.

\begin{abstract}
This article will analyze the involvement of one of the richest families of Brazil Empire with the illegal African trade. The siblings José e Joaquim de Souza Breves, men of prominence in $19^{\text {th }}$ century Brazilian's politics and society, built a real territorial and human empire, formed by thousands of slaves placed in their properties. They certainly built one of the biggest fortunes of that time. From the "south-fluminense" cost until the "Vale do Paraíba", we can find several farms, essentially characterized by the African's presence. Trying to comprehend how the relationship of the Comendadores Breves with the illegal slave trade built specific characteristic the their coastal properties, lighting, in present time, new question about last years of african trade to Brazil .
\end{abstract}

Keywords: Illegal african slave trade. Slavery. Family Breves.

\footnotetext{
${ }^{1}$ Artigo submetido à avaliação em 27/08/2011 e aprovado para publicação em 30/11/2011
} 
José e Joaquim Breves, irmãos em uma extensa família luso-brasileira, vivenciaram praticamente todo o século XIX. A infância de ambos, no início dos oitocentos, coincidiu temporalmente com a afirmação do império luso-brasileiro; a maturidade, com a construção do Império do Brasil; e a velhice, com a derrocada do sistema escravista e consequentemente do Império que ajudaram a construir. O início, o apogeu e a decadência do Vale cafeeiro também cortaram as suas histórias. Por isso participaram de importantes momentos da política imperial, embora em lados opostos. Adversários políticos, com perfis de pensamento diferentes, aproximaram-se em relação a um aspecto da sociedade oitocentista: o tráfico ilegal de africanos. Ambos investiram nesse comércio até quando puderam, inclusive defendendo politicamente a manutenção do ilícito trato e mantendo fazendas destinadas à recepção de africanos recém-chegados da travessia atlântica. A defesa do tráfico talvez tenha sido o maior ponto de convergência entre os Comendadores. Ela unia liberais e conservadores, que, embora utilizassem estratégias diferentes, mostravam-se lado a lado ao insistirem na continuidade do ilícito trato. Os dois irmãos vivenciaram um mesmo tempo de forma bastante diferente, mas estiveram juntos, pelo menos até 1850 , ao apostarem erroneamente na ineficácia da nova lei construída a fim de abolir o tráfico em setembro de 1850. Ao lado da insistência no comércio negreiro, os Souza Breves são conhecidos por edificarem, durante o século XIX, uma imensa fortuna, alicerçada basicamente em terras e escravos.

A conformação de uma das maiores fortunas do Brasil Imperial, exemplificada pelos imensos domínios territoriais e humanos espalhados pela província do Rio de Janeiro, não se explicaria apenas pelas inúmeras toneladas de café exportadas pelas fazendas dos Breves. Apesar de, no início da década de 1860, a família Breves produzir sozinha mais de 1,5\% de todo o café exportado pelo Império do Brasil (TAUNAY, 1939), as maiores fortunas do período não foram construídas a partir das plantações cafeeiras. Como mostraram Fragoso e Rios, o capital usurário representava a mola mestra na construção das grandes fortunas imperiais, revertidas quase sempre em escravos e terras (FRAGOSO e RIOS, 1995). No caso dos Breves, uma atividade, em especial, alicerçou, durante a primeira metade do século XIX, a fortuna dos Comendadores: o tráfico ilegal de africanos.

O comércio negreiro, quando ainda permitido pelas leis brasileiras e internacionais, já era atividade de alto risco. As perdas de capitais investidos poderiam ser totais. Entretanto, apesar dos riscos, a alta lucratividade do negócio motivava o empreendimento em escala atlântica (FLORENTINO, 1997). Com a ilegalidade do comércio de africanos, estabelecida pela lei de 7 de novembro de 1831, e ratificada quase 20 anos depois por uma nova lei em 1850, os riscos que já eram elevados aumentaram. Na década de 1850, apesar de todo o 
empenho das autoridades brasileiras em pôr um ponto final no comércio de almas entre a África e o Império do Brasil, o tráfico continuava motivado, especialmente pelo enriquecimento atrelado ao sucesso do empreendimento negreiro. Durante a ilegalidade, a repressão posta em prática pelas autoridades e a necessidade de agenciar capitais e redes de relações atlânticas afastaram os pequenos comerciantes do lucrativo trato, garantindo o mercado apenas a aqueles que possuíssem capitais suficientes para investir no comércio clandestino (FERREIRA, 1996). No Império do Brasil, os irmãos Breves representavam a face dos novos agentes envolvidos no tráfico de africanos durante a ilegalidade. Como veremos, a família Breves esteve atrelada aos negócios negreiros desde o seu recrudescimento.

Pesquisas sobre o tráfico são categóricas ao afirmar que foi a partir da segunda metade da década de 1830 que o comércio de escravos com a África voltou a tomar força no Império do Brasil (CONRAD, 1985; PARRON, 2009)². Exatamente nessa época os Souza Breves passaram a agenciar o comércio de africanos. Interessante notarmos que eles não apareciam entre os principais negreiros atuantes antes da ilegalidade, pelo menos não os encontramos nas listagens de traficantes da Praça do Rio de Janeiro até o início da década de $1830 .^{3} \mathrm{Na}$ verdade, poderiam até mesmo estar inseridos nos negócios do tráfico, mas com certeza ainda não gerenciavam o comércio de cativos. Os irmãos Breves pareciam inaugurar e bem representar o rol dos novos personagens e das novas estruturas montadas para receber os escravos vindos da África durante a ilegalidade do comércio negreiro.

Durante a ilicitude e, sobretudo, a partir do endurecimento da repressão inglesa, o comércio negreiro mudara nas duas margens do Atlântico (FERREIRA, 1996; CICHELLI, 2006). Na África, o deslocamento dos embarques de escravos do litoral de Luanda, para o norte de Angola ou para a Costa Oriental, tornara-se frequente, principalmente após a abolição do tráfico nas colônias portuguesas em 1836. No Império do Brasil os desembarques também foram reordenados para fugir da repressão. As praias litorâneas, mais afastadas do controle do Estado, passaram a acoitar os africanos traficados. Nelas, novas estruturas foram edificadas para receberem os sujeitos que continuavam chegando, em números crescentes na década de 1840. Novamente os Comendadores Breves exemplificam e agregam sentido à reordenação do tráfico, especialmente porque as suas propriedades do litoral sul-fluminense

\footnotetext{
${ }^{2} \mathrm{O}$ retorno do gabinete conservador, comandado por Bernardo Pereira de Vasconcellos, representou um dos elementos que facilitaram o recrudescimento do tráfico. Exemplar, nesse sentido, foi a atitude de Vasconcellos que propusera na legislatura de 1834, no Senado Imperial, a extinção da lei de 1831. Três anos depois, o próprio autor da lei de 1831, Marquês de Barbacena, faria o mesmo (RODRIGUES, 2000, p.89-90).

${ }^{3}$ Para a listagem dos traficantes atuantes na praça carioca entre 1811-1830, ver: "Apêndice 26" (FLORENTINO, 1997, p. 254-256)
} 
assumiam o papel de portos clandestinos de desembarque negreiro, pelo menos até os primeiros anos da década de 1850 .

Não acreditamos que todo esse sistema surgiria sem o emprego de grandes capitais, gerenciados em uma ampla rede comercial. Da mesma maneira, não seria apenas um novo dispositivo jurídico que transformaria o tráfico em uma atividade ilegal, aos olhos dos fazendeiros e da própria sociedade brasileira. Sabemos que as leis são construídas nos embates políticos e sociais de uma época, quase sempre exemplificando interesses e perspectivas diferenciadas. Nesse sentido, a ilegalidade do tráfico não estava dada na década de 1830, os interesses e as perspectivas estavam dispostos nas discussões no Parlamento brasileiro e na sociedade da época.

Sendo assim, iniciaremos nossa análise evidenciando mais detidamente $o$ envolvimento dos Souza Breves com o tráfico de africanos. Acompanharemos os casos de desembarques de "negros novos" nas margens das suas fazendas litorâneas, no mar de Mangaratiba e de Angra dos Reis. Paralelamente, investigaremos as estruturas das fazendas de Santa Rita do Bracuhy e da Marambaia. Embora tenhamos uma avaliação tardia dessas propriedades, uma avaliada em 1880 e a outra, dez anos depois, poderemos perceber os resquícios daquelas estruturas construídas para receber os africanos traficados na ilegalidade. Certamente teremos uma imagem um pouco distante do fim do tráfico nessas fazendas, entretanto observaremos como estavam organizadas, ou mesmo desorganizadas, as propriedades litorâneas dos Breves no pós-1850. Acreditamos que, entre a década de 1830 e o início dos anos de 1850, elas passaram a suprir a desarticulação do mercado do Valongo e das demais estruturas de recepção dos negreiros que ancoravam na margem brasileira do Atlântico. Concluiremos observando como as estratégias e ações dos Comendadores Breves podem contribuir para que conheçamos o perfil e as perspectivas daqueles sujeitos que por último abandonaram o tráfico de almas entre a África e o Império do Brasil.

\section{Os Souza Breves e o tráfico ilegal de africanos}

\footnotetext{
Mas aqui era o ponto de embarque e desembarque do Comendador Sousa Breves (...) além de ser de desembarque, era de engorda também, sabe?

A história que eu sei (...) que (...), proibiram a venda dos escravos para cá. Mas, não sei como é que fizeram, que ainda roubaram lá oportunidade e arrumaram uns escravos para trazer pra cá, para vender novamente. Raptaram escravos lá, encheram o navio e trouxeram pra cá. Mas veio até aqui, numa ilha com um nome... Como é? Ilha Cunhanbebe. (...) O barco entrava lá, passava pertinho (...) para entrar e trazia o pessoal pra cá (Entrevista com Sr. Manoel Moraes, 27/10/2006. Acervo Petrobrás Cultural Memória e Música Negra. Laboratório de História Oral e Imagem LABHOI, www.historia.uff.br/jongos, acessado em março de 2009).
} 
Manoel Moraes há mais de 80 anos vive nas antigas terras da fazenda de Santa Rita do Bracuhy, em Angra dos Reis. Seus avós maternos e paternos foram escravos do Comendador José de Souza Breves. "Preto Forro", avô paterno, e Antonio Joaquim da Silva, pai de sua mãe, viveram os últimos anos da escravidão na fazenda. Ambos receberam suas alforrias ainda na década de 1870 , e foram citados como legatários da antiga fazenda no testamento do Comendador escrito em 1877 e aberto no ano de 1879. Muito provavelmente foram seus avôs que perpetuaram as histórias do tráfico e da escravidão ao longo dos anos, transmitidas de geração a geração, em um processo de rememoração em que o histórico da fazenda se confundia com as próprias trajetórias familiares dos seus moradores. No caso do Sr. Manoel Moraes, as histórias da escravidão e do tráfico narram também lembranças de família muito vívidas e com referenciais muito fortes na experiência da escravidão nas últimas décadas do século XIX.

Certamente, Antonio Joaquim da Silva, escravo de Breves, encarregado do engenho de cana de açúcar, viveu ou ouviu falar dos inúmeros desembarques de africanos que ocorreram no Bracuhy a partir da década de 1840 (ABREU, 1995, p.167-195). O engenho no qual trabalhava produzia essencialmente aguardente, mercadoria chave no comércio de escravos na costa atlântica da África. Ao analisarmos a fazenda de Santa Rita no final da década de 1870, encontraremos uma área em decadência, praticamente abandonada à própria sorte de seus habitantes. No entanto, antes de nos determos sobre a relação entre a antiga fazenda e o tráfico de africanos, cabe esclarecer alguns pontos importantes sobre o comércio de almas. Como se reorganizara após a ilegalidade? Qual o papel dos Souza Breves no tráfico? E as suas fazendas do litoral, quais funções representavam na reordenação do comércio negreiro após a lei de 1831 ?

No litoral africano, os padrões de abastecimento do tráfico atlântico de escravos se alteraram significativamente já a partir da segunda década do século XIX. A repressão inglesa na África fez com que os traficantes do litoral mudassem suas estratégias de comércio. $\mathrm{O}$ embarque no continente africano deslocou-se de Luanda e dos demais portos centrais da região Centro-Sul para locais mais afastados do litoral, como o norte de Angola e as ilhas da África Oriental. Os portos de Moçambique, Inhambane e Quelimane cresceram significativamente nesse momento, seguindo a tendência de reestruturação do tráfico atlântico de africanos na década de 1830.

No Império do Brasil, a partir da lei de 1831, o tráfico também se modificou, principalmente em termos estruturais. Com o comércio negreiro considerado uma atividade ilegal, consequentemente o mercado do Valongo, responsável por receber e redistribuir os 
escravos pelas fazendas fluminenses, foi fechado, pairando durante poucos anos um vazio sobre onde e como seriam recebidos os escravos que continuariam a vir da África após 1831 . No entanto, rapidamente novos agentes entrariam no ilícito comércio. E com eles novas estratégias para burlar a lei e redefinir os mecanismos de um comércio juridicamente condenado. Ao que tudo indica, rapidamente foram articulados novos portos de desembarque. No caso do Rio de Janeiro, as praias afastadas ao norte e ao sul da Corte foram os locais escolhidos para receber os africanos reduzidos ilegalmente à condição dos escravos. Novos agentes também entraram nesse lucrativo comércio, já em meados dos anos de 1830, com destaque para os fazendeiros fluminenses.

Provavelmente os Breves despontaram nesse comércio ainda na década de 1830, estando entre aqueles primeiros agentes que se lançaram na atividade negreira, considerada à época ilegal pelas leis brasileiras, e por acordos internacionais. Nos litorais das diversas praias afastadas do interior do Império, os desembarques recomeçavam e passavam a contar com a ingerência dos antigos senhores de escravos e fazendeiros de café, sedentos pela mão de obra africana e pelos altos lucros auferidos no tráfico.

Em 1830, no comprovante de concessão e registro da Ordem da Rosa atribuído a Joaquim Breves, encontramos, além do nome completo do fazendeiro, uma referência bastante importante: comerciante de escravos (Documentos Biográficos c 1052,44, Projeto escravos no Brasil, Biblioteca Nacional). A Ordem lhe foi atribuída em um momento conjuntural no qual o envolvimento no tráfico não mancharia a trajetória de Joaquim nem de outros sujeitos atrelados ao comércio negreiro; alguns deles, inclusive, se tornariam políticos proeminentes durante o Segundo Reinado. Entretanto, não podemos afirmar que Breves gerenciasse a finalização do comércio atlântico de africanos no início de 1830. Poderia ser apenas mais um dos agentes envolvidos nos últimos desembarques antes da lei de 7 de novembro de 1831; como também era possível que atuasse nas redes do tráfico interprovincial no Império do Brasil. O que podemos afirmar, com relativa precisão, é o fato de que os negócios negreiros, legais ou não, marcaram logo de início a trajetória dos Souza Breves, assim como representaram uma importância singular na conformação das suas fortunas. Segundo Luís Henrique Tavares, Joaquim Breves estaria ao lado de grandes traficantes, como Manoel Pinto da Fonseca e José Bernardino de Sá, "grandes negreiros no Rio de Janeiro dessa época" (TAVARES, 1988, p.29).

Em 1837, os investimentos da família Breves passavam a se cruzar diretamente com os negócios do tráfico. Conjuntamente com o crescimento das plantações de café no Vale do Paraíba Fluminense, os Comendadores começavam a investir no lucrativo comércio de 
africanos. Nesse mesmo ano, o presidente da Câmara de Mangaratiba, em Ofício ao Governo do Império, informa:

Em 10 de Janeiro [de 1837] (...), por aqui apreendido pelo Juiz de Paz deste distrito o patacho que se diz ser portuguez e que se denomina União Feliz ter-se empregado desde 1835 no ilícito, imoral, e desumano trafico da escravatura, e que acabava de verificar um desembarque de africanos no lugar onde fora apreendido e porque tivesse ingerência nessa embarcação Joaquim José de Souza Breves (Ofício n. 6, Ofícios da Câmara ao Governo do Império, 1832-1846, Fundação Mario Peixoto).

Segundo a Câmara de Mangaratiba, Joaquim não era apenas um exímio comprador de indivíduos reduzidos ilegalmente à escravidão. Mais do que isso, possuía ingerência sobre a embarcação negreira que cruzava o Atlântico nas rotas da ilegalidade. Certamente o empreendimento traficante contava com um apoio logístico para o embarque na África e o desembarque no Brasil. Os negócios da família Breves movimentavam uma ampla rede comercial nas duas margens do Atlântico, envolvendo, além dos Comendadores, outros indivíduos de destaque na sociedade oitocentista. Entretanto, a gerência desse empreendimento, no lado brasileiro da costa, estava nas mãos de Joaquim Breves. E não foi pequeno o seu investimento nessa empreitada. Prova disso encontramos no fato de Joaquim levar até as últimas consequências a viabilidade dos seus negócios, enfrentando, inclusive, as autoridades do Estado Imperial. Certamente o presidente da Câmara de Mangaratiba não estava entre os pares de Breves, tanto que continuou sua denúncia sobre a audácia do fazendeiro-traficante que continuava no ilícito trato a qualquer custo:

\footnotetext{
(...) e conhecendo este [Joaquim Breves] não poder corromper o juiz de paz então em exercício [ ] de viva força asenhorar-se do mesmo Patacho e do [ ] que por cautela estaria depositado no Forte da Guia, e fazê-lo de novo navegar afim de transportar talvez outro carregamento de infelizes, e para esse fim mandou engajar em serra acima gente mercenária da mais ínfima classe, a maior parte seus dependentes os quais armados de diversos modos descerão efetivamente e em sua casa e na de seus protegidos se acoitarão subindo o seu[ ] a 100 ou mais como se manifesta no documento junto marcado em [ ] e porque este indivíduo reconhecesse a dificuldade da empreza vista da vigilância a parte na autoridade a quem diretamente pertencia aconselhar e precaver este atentado, disperadiu-se por então da empreza, e mandou retirar esse indivíduo esperando ocasião mais oportuna para por em execução o seu intento, quando com certeza de bom êxito pudesse efetuar o que premeditará. (...) Por [ ] rivalidade e mesmo por vingança Joaquim José de Souza Breves, Exmo. Sr. ameaça a huma povoação inteira, espalhou o terror entre os habitantes do município e o que mais [ ] disso se vangloria, e impune e audaz, passe entre nós. Ilmo. Homem que se [ ] a mandar vir de Serra Acima, huma quantidade de gente armada para cometer um atentado de tal natureza, é capaz de praticar outros mais [ ] e a vista de hum tal procedimento authorizado está para cometer quantas desvarias conceber em sua escaldada imaginação (Ofício n. 6, Ofícios da Câmara ao Governo do Império, 1832-1846, Fundação Mario Peixoto)
}

Não imaginaria o presidente da Câmara que a imaginação de Joaquim fosse tão longe. Tampouco suporíamos que a audácia do referido fazendeiro seria tão grande. Para sê-la, a ponto de organizar uma incursão ao Forte da Guia para retomar o patacho, era possível que, 
além de possuir ingerência sobre o tumbeiro, poderia ser o próprio Breves o dono da embarcação. Era comum durante a ilegalidade que as embarcações usassem bandeiras falsas para fugiram dos cruzadores britânicos (CONRAD, 1985). Breves poderia manter um navio com documentação portuguesa como forma de burlar a repressão. Ou simplesmente, apenas agenciava o contrabando, sendo responsável pelo desembarque na costa brasileira. Nessa hipótese, todo o fracasso do empreendimento cairia sobre suas costas e seu bolso. Talvez isso ajude a entender a atitude impulsiva e audaciosa de Joaquim ao organizar uma empreitada, com mais de cem homens armados, com a finalidade de resgatar o patacho negreiro. É bastante improvável que Breves estivesse sozinho, certamente o prejuízo da travessia negreira implicaria perdas econômicas e uma possível desarticulação de uma cadeia de relações sociais e econômicas estruturada no Atlântico.

Quase quinze anos após a denúncia da Câmara de Mangaratiba, Joaquim de Paula Guedes Alcoforado, traficante redimido, era contratado pela legação inglesa no Rio de Janeiro com a finalidade de elaborar um detalhado relatório sobre os meandros do comércio ilegal de africanos entre 1831 e 1853. O "Relatório Alcoforado", como ficou conhecido, ratifica os nossos indícios de que os Breves foram pioneiros na retomada do tráfico em meados da década de 1830. Além disso, Alcoforado, que também estava a serviço da Polícia da Corte do Rio de Janeiro, desvenda novos nomes, confirmando a hipótese de um comércio que orbitava em torno da família Breves-Moraes e era realizado em escala atlântica:

Infelizmente o primeiro ambicioso brasileiro que tratou desse tão infame como
repugnante tráfico foi Joaquim Breves, seu sogro e irmão, lançando mão do
aventureiro e degenerado português João Henrique Ulrich (hoje de grande
notabilidade), a quem mandavam à África com grandes negociações
(ALCOFORADO apud FERREIRA, 1995).

Joaquim Breves, seu irmão, e o sogro dos referidos Comendadores, José Gonçalves de Moraes, Barão de Pirahy, empreenderam um negócio em família que funcionava nas duas margens do Atlântico. Além deles, João dos Santos Breves, irmão dos referidos Comendadores, também participara das atividades traficantes. João, ao que parece, administrava armazéns e entrepostos comerciais de propriedade da sua família em Mangaratiba ${ }^{4}$. Poucos sabemos sobre o irmão de José e Joaquim Breves, no entanto, podemos inferir que João exercia importante função nos negócios familiares com a costa africana,

\footnotetext{
${ }^{4}$ Em fevereiro de 1851, quando o delegado de polícia do Rio de Janeiro, Bernardo de Azambuja, apreendeu 199 africanos novos na Marambaia, além de Joaquim encontrava-se na restinga João dos Santos Breves. Segundo os depoimentos colhidos por Azambuja, João era negociante em Mangaratiba. Juízo de Auditoria de Marinha, 1856, Arquivo Nacional. Armando de Moraes Breves, em suas memórias familiares, recorda que: "A ruga mais séria deu-se na ocasião em que alguns barcos ingleses entraram em Angra dos Reis, perseguindo dois navios negreiros (...) os tumbeiros chamavam-se Leopoldina e Januária. O contrabando vinha despachado para João dos Santos Breves, irmão do tio Joáca [Joaquim Breves]" (BREVES, 1966).
} 
atuando na organização dos desembarques em Mangaratiba. Na África, contavam com o agente João Henrique Ulrich para intermediar as negociações no litoral. Desconhecemos a trajetória de João Ulrich, acreditamos ser um negociante, como informa Alcoforado, que enriqueceu com o tráfico e fez fortuna em Portugal.

Mas se contavam com os barracões para armazenar os cativos até o embarque nos tumbeiros, com africanos para abastecer os navios e viabilizar o empreendimento do tráfico, e com Ulrich para fechar os últimos detalhes comerciais da viagem, como era a estrutura do desembarque? Quem os esperava? Onde deveriam desembarcar e aguardar instruções antes de irem para as fazendas? Novamente Alcoforado nos auxilia na construção das respostas:

\begin{abstract}
Em fins de 1835, o tráfico era grande. Em muitos pontos de nossa costa se estabeleceram *barracões e fazendas *apropriadas para se darem este desembarques de africanos; as autoridades de terra que tinham ingerência neste negócio eram os *Juízes de Paz *que no *termo* aonde eram feitas estas especulações tinham como *paga $10,8 \%$ * por cento de cada negro desembarcado (...). Um Joaquim Thomaz de Farias, patrão-mor da Barra de Campos e um marinheiro por nome André Gonçalves da Graça (hoje ambos Comendadores) trataram de fazer um ponto de desembarque um pouco mais ao Norte da Barra de Campos lugar denominado Manguinhos; José Bernardino de Sá e um tal de Veiga estabeleceram próximo a São Sebastião, lugar denominado Itabatinga; (...) *José Breves em Mangaratiba mais adiante na Ilha da Marambaia* (ALCOFORADO, 1853) ${ }^{5}$. (grifos meus)
\end{abstract}

As fazendas da Marambaia e de Santa Rita do Bracuhy estavam entre aquelas propriedades organizadas para receber os africanos recém-chegados da travessia atlântica no período do tráfico ilegal. Após 1830, barracões e fazendas do litoral recriavam as estruturas outrora destruídas pela lei de 7 de novembro de 1831. Canoas, barracões para quarentena e locais de "engorda" conformavam as estruturas de recepção. Indivíduos especializados em se comunicarem com as diferentes nações africanas, os chamados Línguas, em sua maioria escravos ou libertos, vinham nos tumbeiros ou esperavam nas praias a carga humana, junto com os demais sujeitos do empreendimento negreiro. Além deles, outros homens transportavam por terras os "negros novos" para quarentena, em seguida os redistribuíam pelas fazendas da região. São esses sujeitos, ainda pouco conhecidos pela historiografia, que faziam funcionar o tráfico de africanos na clandestinidade, dinamizando o funcionamento das fazendas receptoras de escravos no litoral brasileiro (RODRIGUES, 2006).

O complexo de fazendas da restinga da Marambaia, de propriedade do Comendador Joaquim Breves, no litoral de Mangaratiba, abrigava algumas daquelas fazendas destinadas à

\footnotetext{
${ }^{5}$ Agradecemos ao professor Carlos Gabriel Guimarães, do Departamento de História da UFF, por ceder gentilmente a transcrição do referido documento. $\mathrm{O}$ trecho cedido por Carlos Gabriel não consta no texto transcrito por Roquinaldo Ferreira.
} 
recepção de africanos. Desde o final dos anos de 1830, a restinga funciona como porto seguro para a recepção de escravos. Em 1837 a embarcação Bergantim Leão desembarcou 572 africanos, procedentes do Quelimane (CICHELLI, 2006) ${ }^{6}$. Quase 15 anos depois, em apenas três meses, entre dezembro de 1850 e fevereiro de 1851, foram apreendidos 940 africanos ilegalmente trazidos para o Brasil e desembarcados nas águas da Marambaia (MORAES, 2009).

Em uma dessas apreensões, realizadas entre os dias 1 e 2 de fevereiro de 1851, em incursão à Marambaia, o delegado de Polícia da Corte, Bernardo de Azambuja, após notificar o Comendador, que se encontrava na fazenda, apreendeu espalhados pela restinga 199 africanos, que eram escondidos por um escravo ladino pertencente a Joaquim Breves. Certamente esse cativo era um dos sujeitos que faziam a estrutura da Marambaia funcionar como um exímio porto de desembarque de "negros novos". Nessa mesma época, 450 africanos foram encontrados em um navio encalhado nas margens da Fazenda da Armação, também na Marambaia em fevereiro de 1851. Três meses antes, o tumbeiro Jovem Maria tinha sido flagrado nas águas da restinga com 291 africanos a bordo. Entre os documentos trazidos pelo navio, as autoridades encontraram instruções para que os africanos se dirigissem à fazenda Bom Retiro, na província da Bahia. Coincidentemente uma das fazendas de Joaquim Breves tinha o mesmo nome na década de 1860.

Não foram poucos os casos de contrabando de africanos que envolveram direta, ou indiretamente, os irmãos Souza Breves. Com exceção do desembarque realizado em 1837 na Marambaia, todos os demais incluíram os Comendadores nos autos de investigação. Destacamos abaixo apenas aqueles que se confirmaram, deixando de fora as suspeitas e demais acusações de tráfico ilegal.

\footnotetext{
${ }^{6}$ Segundo a autora, em África embarcaram 855 escravos; e destes, 283 morreram ou foram lançados vivos ao mar durante a viagem.
} 
Tabela 1: Desembarque de africanos nas propriedades dos Souza Breves*

\begin{tabular}{|c|c|c|c|c|c|c|c|}
\hline Ano & Embarcação & Bandeira & Embarque & Desembarque & Proprietário & Embarcados & Desembarcados \\
\hline 1837 & $\begin{array}{c}\text { Patacho } \\
\text { União Feliz }\end{array}$ & $\begin{array}{c}\text { Portugal / } \\
\text { Brasil }\end{array}$ & & Mangaratiba & & & \\
\hline 1837 & $\begin{array}{l}\text { Bergantim } \\
\text { Leão }\end{array}$ & $\begin{array}{c}\text { Portugal / } \\
\text { Brasil }\end{array}$ & Quelimane & Marambaia & & 855 & 572 \\
\hline 1839 & $\begin{array}{c}\text { B. D. João } \\
\text { de Castro }\end{array}$ & $\begin{array}{c}\text { Portugal / } \\
\text { Brasil } \\
\end{array}$ & Moçambique & Marambaia & $\begin{array}{c}\text { Antonio Brás } \\
\text { dos Reis }\end{array}$ & 490 & 444 \\
\hline 1839 & $\begin{array}{l}\text { B. D. João } \\
\text { de Castro }\end{array}$ & $\begin{array}{c}\text { Portugal / } \\
\text { Brasil }\end{array}$ & Moçambique & Marambaia & & 497 & 450 \\
\hline 1839 & $\begin{array}{l}\text { Brigue } \\
\text { Resolução }\end{array}$ & $\begin{array}{c}\text { Portugal / } \\
\text { Brasil }\end{array}$ & Quelimane & Marambaia & & 465 & 421 \\
\hline 1850 & $\begin{array}{l}\text { Iate Jovem } \\
\text { Maria }\end{array}$ & Brasil & & Marambaia & $\begin{array}{c}\text { Vitor } \\
\text { Manoel } \\
\text { Paneto } \\
\end{array}$ & 354 & 291 \\
\hline 1850 & Edelmando & & Ibo & Marambaia & $\begin{array}{c}\text { Francisco da } \\
\text { C. Ramos }\end{array}$ & 683 & 559 \\
\hline 1851 & & & & Marambaia & & & 199 \\
\hline 1851 & $\begin{array}{c}\text { Patacho } \\
\text { Atividade }\end{array}$ & & & Marambaia & & & 455 \\
\hline 1851 & $\begin{array}{l}\text { Brigue } \\
\text { Destro }\end{array}$ & Brasil & & Rio de Janeiro & $\begin{array}{c}\text { Joaquim } \\
\text { Breves }\end{array}$ & 657 & 457 \\
\hline 1852 & $\begin{array}{c}\text { Brigue } \\
\text { Camargo } \\
\end{array}$ & U.S.A & Quelimane & Bracuhy & & 550 & 540 \\
\hline \multicolumn{6}{|l|}{ Total } & 4551 & 4388 \\
\hline
\end{tabular}

* Consideramos também os casos de desembarques que envolveram os Comendadores, mas não se deram exatamente nas suas fazendas, como nos desembarques do Patacho União Feliz, em 1837, e Brigue Destro em 1851.

Fontes: The Trans-Atlantic Slave Trade Databese Voyages. $<$ http://www.slavevoyages.org/tast/index.faces $>$, acessado durante o mês de setembro de 2009. Juízo de Auditoria de Marinha - 1856. № 478; M: 2259; Gl. A, Arquivo Nacional. Ofício n. 6, Ofícios da Câmara ao Governo do Império, 1832-1846, Fundação Mario Peixoto.

Entre 1837 e 1852, tivemos a confirmação de onze desembarques envolvendo os Breves ou suas propriedades, a grande maioria nas proximidades da Marambaia. Como vimos, os Comendadores foram uns dos primeiros indivíduos a retomarem o comércio de africanos e os últimos a abandoná-lo. Nesse período de 15 anos, desembarcaram nas proximidades de suas fazendas cerca de 4388 africanos. Considerando que só uma ínfima minoria dos casos eram averiguados e investigados pela Polícia da Corte, e na década de 1850 pela Auditoria Geral da Marinha, podemos supor que esses números fossem muito maiores. Não é exagero afirmar que os irmãos Breves agenciaram a vinda de milhares de africanos para o Brasil durante a clandestinidade do comércio negreiro, e que boa parte desses sujeitos foram reduzidos ilegalmente ao cativeiro nos plantéis espalhados pelas fazendas do Vale do Paraíba.

Chama a nossa atenção que a maioria das viagens começassem no Rio de Janeiro. Do Bergantim Leão, que atuava no tráfico em 1837, ao Brigue Camargo, último desembarque confirmado nas propriedades dos Breves, o caminho era semelhante: Rio de Janeiro - África - 
Rio de Janeiro. Na maioria das vezes a finalização se dava na Marambaia. Nos dois casos citados, ambos os navios partiram do Rio de Janeiro rumo a Quelimane. Retornaram com mais de 500 cativos cada um. Além deles, os brigues D. João de Castro e Edelmando construíram trajetórias muito semelhantes: o primeiro saindo por duas vezes do Rio de Janeiro para Moçambique, e o segundo para Ibo, na África Ocidental. ${ }^{7}$ Em outras palavras, boa parte dos traficantes do período ilegal do comércio negreiro, assim como fizeram seus antecessores durante a legalidade (FLORENTINO, 1997 e FRAGOSO, 1998), movimentavam suas redes transoceânicas a partir do litoral do Rio de Janeiro.

Também nos impressiona que das seis procedências registradas, cinco delas relacionavam-se ao litoral de Moçambique. A importância da África Oriental no período do tráfico ilegal é reconhecida por vários historiadores; no entanto, ela parece ter sido muito maior do que se tem imaginado. Entre os onze navios registrados, no mínimo cinco deles saíram dos portos de Moçambique e Quelimane. Estranhamente uma das embarcações catalogadas teve em Ibo, próximo à atual Nigéria, sua principal praça de aquisição de cativos. Os 683 africanos embarcados em Ibo chegaram ao litoral sul-fluminense em 1850. Em relação aos demais, não encontramos informações precisas sobre a procedência. Entretanto, pelos escravos apreendidos no Iate Jovem Maria, no Patacho Atividade e na embarcação que trouxe 199 africanos para a Marambaia em 1850, acreditamos que esses embarques tenham se dado na costa central-atlântica africana, provavelmente nos portos ao norte de Luanda (MORAES, 2009).

Entre as bandeiras dos navios a maior parte era portuguesa ou brasileira. Sobre as tripulações temos poucas informações, com exceção do Iate Jovem Maria e do Brigue Camargo. Nessas embarcações a composição da tripulação variava entre espanhóis, norte-americanos e ingleses. No Iate encontramos essencialmente espanhóis, enquanto no Camargo viajavam americanos, ingleses e espanhóis. Interessante notarmos a ausência de portugueses ou brasileiros. Nesse momento, o comércio negreiro maximizava suas redes internacionais, acionando indivíduos na Europa e nos dois continentes banhados pelo Atlântico.

Oito entre os onze desembarques ocorreram na Marambaia. A restinga do Comendador concentrava a finalização do empreendimento traficante. Entre os demais, duas embarcações atracaram nesse mesmo litoral: uma no ano de 1837, em Mangaratiba, e a outra

\footnotetext{
${ }^{7}$ Cabe lembrar que o tráfico ao norte da linha do Equador era ilegal desde 1815, nos termos do tratado assinado entre Portugal e Grã-Bretanha. De acordo com o documento, ficava proibido a todo vassalo da Coroa portuguesa comprar ou traficar escravos em qualquer lugar da Costa da África ao norte do Equador (apud CICHELLI, 2006).
} 
em Angra dos Reis, na fazenda de Santa Rita, quinze anos depois. Nos dois casos encontramos o envolvimento direto dos Comendadores Joaquim e José Breves.

Em mais um dos desembarques ocorridos fora da Marambaia, deparamos-nos com a presença ilustre de Joaquim Breves. Em 1851 era ele o proprietário do Brigue Destro, que desembarcou 457 africanos no Rio de Janeiro. Nesse caso, com seu próprio tumbeiro, Breves não utilizou suas fazendas litorâneas para finalização do empreendimento. Optou por atracar o brigue em outra parte do litoral fluminense, fugindo da visada restinga de sua propriedade.

Outros senhores também figuraram como proprietários de tumbeiros atracados na Marambaia de Breves. Entre eles, Antônio Brás dos Réis, Vitor Manoel Paneto e Francisco da Costa Ramos. O primeiro, dono do Brigue D. João de Castro, capturado duas vezes pelos britânicos em 1839. No primeiro caso, o tumbeiro desembarcou 450 cativos no litoral da Marambaia, já na segunda viagem 444 africanos foram levados da restinga do Comendador para as fazendas do Vale do Paraíba. ${ }^{8}$ Vitor Panedo e Francisco Ramos eram proprietários, respectivamente, do Jovem Maria e do Edelmando, apreendidos na mesma restinga em 1850.

Provavelmente, Joaquim Breves agenciava na Marambaia a última fase do empreendimento traficante, especialmente a partir dos últimos anos da década de 1840. Mais da metade dos desembarques registrados ocorreram no pós-1850. Os demais se deram nos anos de 1837 e 1839. Não há nenhuma evidência de navios capturados na década de $1840 .{ }^{9}$ Não acreditamos que a Marambaia e o Bracuhy tenham deixado de receber africanos ilegalmente durante aqueles anos. Mais provável é que o Império tenha sido bastante permissivo em relação ao tráfico nas fazendas afastadas da Corte. O domínio político conservador, consolidado nos anos de 1840, assegurava não só o monopólio do tráfico para os seus pares, como também adiava para o início da década seguinte a perseguição aos tumbeiros e aos desembarques realizados ao longo da costa brasileira.

Outro dado relevante nessas viagens se relaciona aos escravos traficados que morreram a caminho do cativeiro no Brasil. Os avanços tecnológicos dos negreiros nem sempre garantiam uma redução significativa da taxa de mortalidade. Por exemplo, o tumbeiro Bergantim Leão perdeu cerca de 33,1\% dos seus cativos em 1837. Quatorze anos depois, o Brigue Destro, de propriedade de Joaquim Breves, amargou um prejuízo significativo, com a morte de 30,4 \% dos escravos a bordo. Embora essas taxas sejam bastante altas, elas não correspondem à totalidade dos desembarques. Nos casos analisados, as taxas oscilavam

\footnotetext{
${ }^{8}$ A coincidência em relação ao nome do navio, assim como ao seu capitão (Vicente de Freitas Serpa), que comandou ambas as viagens, deu-nos certeza de estarmos diante do mesmo brigue. The Trans-Atlantic Slave Trade Databese. Voyages 1948 e 900153.

${ }^{9}$ Entre os desembarques registrados no banco de dados do projeto Voyages, apenas o Bergantim Leão não foi apreendido.
} 
bastante. Exemplo disso é que em 1839, nas duas viagens do Brigue D. João de Castro, a taxa de mortalidade girava em torno de $10 \%$, praticamente a mesma do Brigue americano Camargo, que registrou mortalidade em torno 9,1\% em 1852. Essas variáveis não eram fixas e se relacionavam tanto com o itinerário das viagens e seus portos de origem, quanto com a finalização do empreendimento. A própria lógica de maximização dos lucros de alguns traficantes, que abarrotavam os tumbeiros com centenas de africanos, aumentava significativamente esses índices. Emblemático, nesse sentido, é o caso do Bergantim Leão, que embarcou 855 africanos em 1837 e, ao mesmo tempo, amargou a maior taxa de mortalidade entre os tumbeiros registrados.

\section{As fazendas de Santa Rita do Bracuí e da restinga da Marambaia}

Não restam dúvidas de que as fazendas litorâneas dos Comendadores eram estruturadas para recepção de africanos recém-chegados da travessia atlântica. Algumas delas, além de possuírem uma estrutura para o desembarque de africanos, tinham se organizado produtivamente para o empreendimento negreiro. É o caso da Fazenda Santa Rita do Bracuhy, de propriedade de José Breves, adquirida por compra em 30 de maio de 1829.

$\mathrm{Na}$ avaliação do espólio do Comendador José de Souza Breves, encontramos 11 fazendas, duas delas no litoral sul-fluminense, na extinta Freguesia de Nossa Senhora da Conceição da Ribeira em Angra dos Reis; eram elas: Santa Rita do Bracuhy e a Fazenda de Jurumirim. Em 1881 ambas foram avaliadas. Salta aos olhos o estado de abandono em que se encontravam. Enquanto nas outras propriedades inúmeros escravos foram listados, diversos bens avaliados, entre imóveis e semoventes, as duas propriedades do litoral parecem abandonadas à sorte dos seus próprios habitantes.

Em 1881, o Bracuhy contava com dois mil, seiscentos e quarenta metros de terras de frente, e fundos "até a mais alta serra do mar" (Inventário de José Breves, 1881), avaliados em dois mil Réis cada metro, totalizando cinco Contos e duzentos mil Réis. Entre as benfeitorias da fazenda encontramos uma casa de vivenda bastante estragada, dois lances de casas que serviam como paiol, além de uma casa com rancho ao lado para guardar canoas. As edificações estavam em ruínas no início dos anos de 1880. Ao que nos parece há tempos não se produzia em Santa Rita. Havia na fazenda apenas vinte enxadas, dez foices e dois machados de serviço de roça, tudo avaliado em míseros oito mil Réis. Havia apenas um pequeno canavial, um pomar e alguns cafezais, que somados não chegavam a meio Conto de Réis. 
O que realmente encarecia a fazenda era sua antiga estrutura de produção de aguardente, que nessa época também estava em decadência, como nos mostra a avaliação feita em 1881. Dessa antiga estrutura existiam quatro carros de bois, próprios para condução de cana, que, somados aos semoventes e trinta e seis bois de carro, chegavam a um Conto, cento e sessenta mil Réis. Isoladamente, o bem mais valioso da antiga fazenda era uma casa de telha, com engenho, moendas, alambique, tonéis e outros elementos para a produção de aguardente, tudo visto e avaliado em um Conto de Réis. Somando o engenho, com os carros de bois e seus respectivos semoventes, destinados ao transporte da cana e seus derivados, chegamos a quase $50 \%$ do valor de referência da propriedade. Isso demonstra que nas décadas anteriores a estrutura produtiva de Santa Rita estava voltada para produção da cana e de seus derivados, especialmente a aguardente.

Como demonstrou Roquinaldo Ferreira, a Geribita, conhecida popularmente como cachaça, era uma das mercadorias mais valorizadas no comércio de escravos no interior do continente africano (FERREIRA, 2002). Nas rotas de atuação portuguesa, os produtos utilizados no tráfico eram essencialmente produzidos em solo brasileiro, tendo destaque a aguardente, o açúcar e a farinha de mandioca (FERREIRA, 1996). Nesse sentido, a família Breves mostrava-se bastante conectada às preferências dos mercadores africanos. Produzindo Geribita, atendiam às demandas do tráfico, multiplicando os desembarques de africanos no litoral brasileiro. Provavelmente João Henrique Ulrich, agente dos Souza Breves em África, comercializou a aguardente do Bracuhy e de outras fazendas litorâneas dos Breves na margem africana do Atlântico.

Além da decadente fazenda analisada, encontramos uma pequena propriedade denominada Jurumirim, no lugar de mesmo nome, formada em sua maior parte por 528 metros de terras na Ilha da Barra, também na Freguesia da Ribeira. A descrição no inventário foi muito sucinta, demonstrando que havia apenas terras e poucas construções, praticamente abandonadas. Além de Jurumirim, José possuía também uma área denominada Ilha Comprida, próxima a Mambucaba. O Comendador deixara a ilha em usufruto dos pescadores que nela viviam e dos próprios moradores de Santa Rita.

Entre os domínios litorâneos dos Comendadores, a Marambaia configurava-se como a principal porta de entrada de milhares de africanos reduzidos ilegalmente à escravidão. Ligação entre o litoral de Mangaratiba e a imensidão do Atlântico, a restinga se tornara um porto seguro para o desembarque de africanos. Em meados do século XIX, o comércio clandestino passaria a ser tão frequente que mesmo o proprietário da restinga admitia as ocorrências dos desembarques. 
A restinga da Marambaia foi comprada do Sr. Guedes e Irmão em 17 de abril de 1847. A avaliação da fazenda, em 1890, demonstra que há tempos aquela propriedade estava abandonada e improdutiva. Entre os três primeiros dias do mês de Setembro, os avaliadores juramentados no processo descreveram minuciosamente a restinga do Comendador. Logo de início, observamos que o complexo da Marambaia era bem mais estruturado do que o de Santa Rita, principalmente pelo número de construções, móveis e canoas. No entanto, ao analisarmos mais detidamente a documentação, percebemos que o abandono na Marambaia era muito semelhante ao do Bracuhy, inventariado dez anos antes no espólio de José Breves. $\mathrm{Na}$ descrição das casas e de alguns móveis, observamos o uso, com frequência, de expressões que denotam esse abandono. Construções em mau estado, ou em ruínas, reincidentemente aparecem nas falas dos avaliadores.

Outra particularidade da Marambaia era o complexo de propriedades que a compunha. A fazenda da Armação parecia ser a principal delas. Lá estava o bem mais valioso inventariado:

uma casa de vivenda, comprida com varanda, na frente envidraçado, na fazenda denominada Armação, assoalhada e forrada, com diversos quartos e salas e cozinha e outras dependências, parte em bom estado e parte em mau estado, visto e avaliada por dois Contos de Réis - 2:000\$000 (Inventário Joaquim Breves, 1890. p. 294).

Até mesmo o bem mais valioso da Marambaia estava se deteriorando, aparentemente abandonado no final do século XIX. Era na Armação que se encontravam importantes construções do recente passado escravista, como a casa de vivenda, que servira outrora de hospital, avaliada em 250\$000 Réis. Além dela, mais outras cinco construções pareciam seguir o mesmo caminho, servindo de abrigo para gados, cavalos e chiqueiros para os porcos. Segundo consta no auto de avaliação da propriedade, os chiqueiros estavam ao lado da antiga enfermaria, evidenciando uma reestruturação do espaço após a abolição da escravidão. Reorganização semelhante deve ter ocorrido com o fim do tráfico de africanos, finalidade específica das propriedades da restinga da Marambaia.

A cerca de uma légua da Armação encontramos a fazenda da Serra d'Água, composta de duas casas erguidas sobre pilares de pedra, e uma capela de Nossa Senhora da Conceição construída em 1851. As duas casas, assim com as anteriores, encontravam-se em ruínas. Além das fazendas, Joaquim Breves mantinha três ilhas em frente à restinga: Saracura, Bernarda e Papagaio fechavam o complexo da Marambaia. Certamente a ilha do Papagaio era a menor delas, apreçada em um terço (50\$000 Réis) do valor das demais. De fato, o que enriquecia o espólio deixado pelo Comendador era a imensa restinga, descrita como ilha da Marambaia, avaliada em duzentos e noventa e cinco Contos de Réis (295:000\$000), em 3 de Setembro de 
1890. O valor do Complexo da Marambaia era 59 vezes maior do que a fazenda do seu falecido irmão no mesmo litoral.

Apesar de toda a vastidão da restinga, o abandono socioprodutivo era a marca das antigas propriedades do litoral sul-fluminense, não só no final da década de 1880, mas durante a segunda metade do século XIX. Esse processo ficou evidente a partir da avaliação da antiga fazenda de Santa Rita, mas se torna muito mais claro ao analisarmos as benfeitorias da Marambaia. Em 1890, tanto na fazenda da Armação quanto na Serra d'Água, as únicas plantações existentes eram os mil pés de coqueiros da Bahia, espalhados pelas referidas propriedades e avaliados em mil Réis cada um. Ao longo de toda avaliação, há apenas uma referência indireta às antigas culturas agrícolas, exatamente no momento em que se avaliava um antigo engenho na praia da Armação para secagem dos grãos de café. Pela quantidade de coqueiros e inexistência de qualquer outra cultura, que ao menos valesse a pena ser inventariada, supomos que há tempos a Marambaia fosse uma daquelas propriedades sem finalidade específica após o fím do tráfico de africanos. A partir dessa perspectiva, compreendemos o abandono da restinga à própria sorte dos seus habitantes, ainda no início da segunda metade do século XIX.

Restaram aos herdeiros da Marambaia, além das construções em ruínas, alguns animais, móveis e canoas. Da antiga casa do Comendador, sobraram apenas mesas e cadeiras, em mau estado, dois pianos e uma canoa grande de Jequitibá, certamente usada no transporte entre o litoral de Mangaratiba e a restinga. No dia 4 de setembro de 1890, os avaliadores juramentados deixaram a Marambaia, seguindo para o Saco de Mangaratiba, onde em apenas um dia inventariaram as construções em ruínas e uma chácara nessa mesma praia. Reminiscências de uma época marcada pelos altos lucros da exportação do café e pela ilegalidade do tráfico internacional de africanos.

É intrigante perceber o abandono e a decadência dessas fazendas do litoral sulfluminense, em contraponto com a opulência das demais propriedades da família Breves no Vale do Paraíba no final da década de 1870. A lei de 1850, ao reafirmar a ilegalidade do tráfico, parece ter mudado, em médio prazo, a paisagem social das fazendas do litoral. O fim do tráfico de africanos, gradativamente construído na primeira metade da década de 1850 , alterou profundamente a rotina das fazendas do sul da província do Rio de Janeiro. As estruturas do tráfico clandestino deveriam ser desmontadas, ou simplesmente abandonadas, e as fazendas que as englobavam, reestruturadas, ou deixadas a cargo dos seus moradores, em sua maioria escravos e libertos. Esse parece ter sido o destino da Fazenda de Santa Rita do Bracuhy e do complexo da Marambaia, logo após o fim do tráfico atlântico de escravos. 
Talvez, por isso, para os que permaneceram na restinga, suas identidades se relacionariam diretamente com as antigas histórias dos últimos desembarques de africanos, possivelmente vivenciadas, direta ou indiretamente, por seus pais e avós. Ao encontrar os que permaneceram na ilha em 1927, Assis Chateaubriand registrou o que disseram os últimos escravos do Comendador. Chateaubriand encontrou Adriano Júnior e Gustavo Victor. Adriano havia trabalhado na fazenda S. Joaquim da Grama e tinha aproximadamente 75 anos. Chateaubriand não precisa a idade de Gustavo Victor, no entanto, diz aparentar ser mais velho que Adriano. Ao ser perguntado aquele sobre seu antigo senhor, Gustavo foi direto ao relacionar a restinga ao comércio de africanos: "Gente vinha de baía d'Angola premero pra aqui. Engordava, e depois ia pra roça, trabaiá no cafezá” (CHATEAUBRIAND apud BREVES, s/d, p. 749).

Indo além, sobre seu antigo senhor, Gustavo Victor lembrava o seguinte: "Era um veio bão. Quando via nego assentado, depois do serviço, apreguntava se nego tava triste, e mandava reunir a senzala para dançar o cateretê e o batuque, fazendo tocar o bumba de barriga" (CHATEAUBRIAND apud BREVES, s/d, p. 749).

O tráfico na Marambaia se confundia com a própria trajetória dos libertos e seus descendentes. Da conformação das fazendas aos indivíduos que lá permaneceram, o infame comércio parecia atribuir sentido para a história daquela restinga, na interseção entre passado e presente. Certamente Gustavo e Adriano teriam muito mais a contar a Chateaubriand, faltou-lhe apenas o registro, ou um pouco do espírito do historiador.

\section{A ilegalidade e seus novos agentes traficantes}

As lembranças rememoradas sobre o comércio de escravos, as fazendas de engordas e os antigos portos de desembarques conformaram o ponto de partida da pesquisa exposta neste texto. Os depoimentos de Manoel Moraes e de outros moradores das antigas fazendas litorâneas dos Comendadores Breves foram os nossos cicerones para adentrarmos nos últimos anos do tráfico ao sul da província do Rio de Janeiro. As memórias de descendentes dos antigos escravos dos Comendadores, ao serem acionadas, para além das disputas políticas e territoriais que demarcam seu campo de produção, reacendem velhas questões e colocam novos problemas para a história social da escravidão e do tráfico de africanos nos oitocentos ${ }^{10}$.

\footnotetext{
${ }^{10}$ Vale enfatizar que as antigas fazendas litorâneas dos Comendadores emergem no início do século XX como Comunidades Remanescentes de Quilombo, nos termos do artigo 68 dos ADCT da Constituição brasileira de 1988.
} 
A rearticulação do comércio negreiro nas duas margens do Atlântico, após a ilegalização do tráfico na costa brasileira em 1831, e cinco anos depois nas colônias portuguesas, em 1836, demandou a construção de novas redes comerciais, assim como reordenou as sociabilidades e os espaços litorâneos destinados ao comércio de escravos. Fossem em águas brasileiras, ou nas praias da Costa da África, novos agentes despontaram no trato ilegal da carne humana, e para tanto se valeram da conivência das autoridades e da própria sociedade local. O imperativo da propriedade, atrelado ao governo da Casa, garantiam, até certo momento, no caso brasileiro até setembro de 1850, a proteção necessária aos empreendimentos traficantes. A última fase dos negócios, o desembarque dos africanos reduzidos ilegalmente à escravidão, contava com novas estruturas organizadas em fazendas litorâneas destinadas, quase que exclusivamente, à recepção dos novos cativos e às demais demandas do comércio negreiro. Em resposta ao desaparecimento do Valongo no Rio de Janeiro e dos demais mercados de escravos nas outras províncias, surgiram novas propriedades que, para além de receberem os negros da costa, montavam seus próprios mercados de escravos:

(...) tenho de participar a V. Ex. ${ }^{a}$ que fui informado que os dois irmãos, Joaquim José de Sousa Breves e José de Sousa Breves, convidaram diversos fazendeiros dos Municípios de S. João do Príncipe, e Pirahy a estarem * para compras uma porção d'Africanos, que mandaram vir de Costa de Leste em seu navio, que deve aportar à Província o Rio de Janeiro, demandando especialmente a parte dela compreendida entre a Guaratiba, e Angra dos Reis, e que aquele navio deve chegar em dias deste mês, ou do próximo futuro" (Secretaria de Polícia da Corte, Reservado, fevereiro de 1854, Série Justiça, IJ6 468, Arquivo Nacional) (grifos meus).

A dinâmica do tráfico, durante a clandestinidade, demandou para além de uma reordenação espacial dos desembarques a construção de novas estruturas que viabilizassem a finalização do empreendimento traficante. Elas iam desde canoas que faziam a travessia entre os tumbeiros e a terra firme, passando pelos barracões para recepção dos negros novos, consagrados na memória local como locais de "engorda"; e como última etapa restava a comercialização e a redistribuição desses indivíduos reduzidos ilegalmente à escravidão. As propriedades destinadas à última fase do comércio negreiro funcionavam ativamente até o início dos anos de 1850, mas logo em seguida aparecem abandonadas nos autos de descrição de bens. Na segunda metade da década de 1850 perderam sua principal funcionalidade: abastecer a demanda por mão de obra no próspero Vale do Paraíba.

Os Breves representaram a face ainda pouco conhecida dos homens de negócios que atuaram no ilícito trato a partir de meados da década de 1830 , e que nele permaneceram no início dos anos de 1850. Nesse período solidificaram as redes transatlânticas que faziam 
funcionar os empreendimentos traficantes através de agentes na África, como no caso de João Henrique Ulrich. Quando necessário, acionavam laços pessoais e comerciais com influentes negreiros, e assim possivelmente o fizeram com o famoso traficante espanhol Francisco Ruviroza y Urzellas, ou com o comerciante português José Bernardino de Sá, com quem os Comendadores nutriam relações de amizade e lucrativos negócios (PESSOA, 2010).

Nas fazendas dos Comendadores, o amplo envolvimento como o tráfico internacional de africanos, durante a clandestinidade, refletia claramente na conformação das suas escravarias. Para o caso das comunidades escravas das fazendas de Joaquim Breves, encontramos forte presença de africanos procedentes das regiões de envio menos expressivas no início do século XIX, e que ganharam representatividade no período da ilegalidade, como o caso dos portos de Cabinda e da ilha de Moçambique (PESSOA, 2010).

Dito de outro modo, boa parte dos africanos traficados pelos Comendadores foram enviados para suas grandes fazendas no Vale cafeeiro fluminense e lá vivenciaram o cotidiano do cativeiro ilegal no Império, que ainda se convencia da necessidade de abolir o comércio negreiro em escala atlântica. Só nos primeiros anos da década de 1850, o Estado Imperial transformou na prática o tráfico em um comércio infame, através das incursões nas fazendas litorâneas, do inquérito dos indivíduos escravizados e da responsabilização criminal dos negociantes envolvidos com o comércio de africanos. Vale destacar que em 1851 as fazendas da Marambaia e do Bracuhy foram ocupadas pela Polícia da Corte, e seus escravos inquiridos. Nesse mesmo ano, Joaquim Breves era condenado em primeira instância pelo crime de pirataria.

Apesar disso, o Estado Imperial ratificara o cativeiro ilegal de milhares de africanos espalhados pelas fazendas fluminenses e comercializados até a lei de setembro de 1850 . Assim, os africanos das fazendas dos Breves, que desembarcaram antes da nova lei, permaneceriam no cativeiro. Em carta ao dono do Bracuhy, Euzébio de Queirós evidenciou a posição do Estado em relação à matéria. Reforçou que as incursões se realizavam apenas em busca dos africanos reduzidos à escravidão após a lei de 1850. Assim, garantia a paz dos senhores que formaram suas extensas escravarias na ilegalidade. Paramos por aqui, com as palavras do Ministro que sintetiza a cumplicidade do Estado brasileiro com a violação da lei de 7 de novembro de 1831 e consequentemente com o cativeiro ilegal de quase um milhão de indivíduos ${ }^{11}$ :

(...) é o que disse até no Parlamento isto é quando o governo não iria dar buscas nas fazendas para resolver o passado (...) Pode ser que a audácia das especulações o leve a proceder com mais algum rigor ou outra vez, mais creio que nem se ultrapassarão

\footnotetext{
${ }^{11}$ Sobre os números do tráfico, ver GOULART, 1949; BETHELL, 1979; ELTIS, 1987.
} 
os limites da necessidade, nem se resolvem o passado (...) Qualquer busca que se dê é para procurar os negros agora importados [a partir de setembro de 1850], e nunca para entender com o passado (Minuta de Resposta. 1853, Museu Histórico Nacional, Coleção Euzébio de Queiróz, EQcr 79/1)

\section{Referências}

\section{Documentos}

Carlos Eduardo de Almeida Barata. Os Breves Abastados Proprietários, www.hegallery.com.br/genealogia, acessado em 30/3/2009. 
Documentos Biográficos c 1052,44, Projeto escravos no Brasil, Biblioteca Nacional.

Entrevista com Sr. Manoel Moraes, 27/10/2006, Acervo Petrobrás Cultural Memória e Música Negra, Laboratório de História Oral e Imagem (LABHOI),

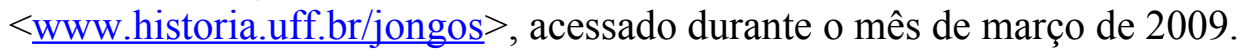

Inventário de José de Souza Breves, Museu da Justiça do Estado do Rio de Janeiro.

Inventário de Joaquim José de Souza Breves, Museu da Justiça do Estado do Rio de Janeiro.

Joaquim de Paula Guedes Alcoforado História sobre o infame negócio de africanos da África Oriental e Ocidental, com todas as ocorrências desde 1831 a 1853. Transcrito por Roquinaldo Ferreira, Revista Estudos Afro-Asiáticos, nº 28, outubro de 1995, pp. 219-229.

Jornal do Commércio, 6/3/1851, Biblioteca Nacional.

Juízo de Auditoria da Marinha, 1856, nº 478, M: 2259, G1. A, Arquivo Nacional.

Ofício n. 6, Ofícios da Câmara ao Governo do Império, 1832-1846, Fundação Mario Peixoto.

Minuta de Resposta. 1853, Coleção Euzébio de Queiróz, EQcr 79/1, Museu Histórico Nacional.

Secretaria de Polícia da Corte, Reservado, fevereiro de 1854, Série Justiça, (IJ6 468), Arquivo Nacional.

The Trans-Atlantic Slave Trade Databese Voyages $<$ http://www.slavevoyages.org/tast/index.faces $>$, acessado durante o mês de setembro de 2009.

\section{Bibliografia}

ABREU, Martha. O caso do Bracuhy In: MATTOS, Hebe e SCHNOOR, Eduardo. (Orgs.) Resgate: Uma Janela para o Oitocentos. Rio de Janeiro: Top Books, 1995.

ARRUTTI, José Maurício (coordenador). Laudo antropológico da comunidade remanescente de quilombo da ilha da Marambaia. Koinonia / Projeto EGBÉ - Territórios Negros, 2003.

BETHELL, Leslie. A abolição do tráfico de escravos no Brasil. Rio de Janeiro: Editora Expressão e Cultura, 1976.

BREVES, Armando de Moraes. O Reino da Marambaia. Rio de Janeiro: Gráfica Olímpica Editora, 1966.

BREVES, Reynato. A Saga dos Breves. Sua Família, Genealogia, História e Tradições. Rio de Janeiro: Ed. Valença S.A, s/d.

CICHELli, Ana Flávia. Tráfico Ilegal de Escravos: Os Caminhos que Levam a Cabinda. Dissertação de Mestrado em História. Niterói: UFF, 2006. 
CONRAD, Robert. Tumbeiros. O Tráfico de Escravos para o Brasil. São Paulo: ed. Brasiliense, 1985.

ELTIS, David. Economic growth and the ending of the transatlantic slave trade. New York, University Press, 1987.

FERREIRA, Roquinaldo. Dos Sertões ao Atlântico: Tráfico Ilegal de Escravos e Comércio Lícito em Angola, 1830-1860. Dissertação de Mestrado em História. Rio de Janeiro: UFRJ, 1996. 219-229.

Relatório do Alcoforado. Estudos Afro-Asiáticos, no 28, outubro de 1995. p.

Dinâmica do comércio intra-colonial: Geribita, panos asiáticos e guerra no tráfico angolano de escravos. In: FRAGOSO, João; BICALHO, Maria Fernanda e GOOUVÊA, Maria Fátima (Orgs.). O Antigo Regime nos Trópicos: a Dinâmica Imperial Portuguesa (Séculos XVI-XVIII). Rio de Janeiro: Civilização Brasileira, 2002.

FLORENTINO, Manolo. Em Costas negras. Uma História do Tráfico de Escravos entre a África e o Rio de Janeiro. São Paulo: Companhia das Letras, 1997.

FRAGOSO, João. Homens de Grossa Aventura. Acumulação e Hierarquia na Praça Mercantil do Rio de Janeiro 1790-1830. Rio de janeiro: Civilização Brasileira, 1998.

FRAGOSO, João e RIOS, Ana Lugão. "Um Empresário Brasileiro nos Oitocentos" In: MATTOS, Hebe e SCHNOOR, Eduardo. (Orgs.) Resgate: Uma Janela para o Oitocentos. Rio de Janeiro: Top Books, 1995.

GOULART, Maurício. A escravidão Africana no Brasil: das origens à extinção do tráfíco. São Paulo: Livraria Martins Editora, 1949.

MATTOS, Hebe e SCHNOOR, Eduardo. (Orgs). Resgate: Uma Janela para o Oitocentos. Rio de Janeiro: Top Books, 1995.

MORAES, Daniela Paiva Y. A Capital marítima do Comendador: a atuação da Auditoria Geral da Marinha no Julgamento sobre a liberdade dos africanos apreendidos na ilha da Marambaia (1851). Dissertação de Mestrado em História. Rio de Janeiro: Unirio, 2009.

MOTTA, Márcia. Ilha da Marambaia: História e Memória de um lugar. In: . e GUIMARÃES, Elione (Orgs.) Campos em Disputas: História Agrária e Companhia. São Paulo: Annablume, 2007.

PARRON, Tâmis. A Política da Escravidão no Império do Brasil, 1826-1865. Dissertação de Mestrado em História. São Paulo: USP, 2009.

PESSOA, Thiago Campos. O Império dos Souza Breves nos Oitocentos: Política e escravidão nas trajetórias dos Comendadores José e Joaquim de Souza Breves. Dissertação de Mestrado em História: UFF, 2010.

RODRIGUES, Jaime. O Infame Comércio. Propostas e Experiências no Final do Tráfíco de Africanos para o Brasil (1800-1850). São Paulo: Ed. UNICAMP / CECULT, 2000. 
De Costa a Costa. Escravos, Marinheiros e Intermediários do Tráfico Negreiro de $\overline{\text { Angola }}$ ao Rio de Janeiro (1780-1860). São Paulo: Companhia das Letras, 2005.

TAUNAY, Afonso de E. História do Café no Brasil. Rio de Janeiro: Ed. do Departamento Nacional do Café, 1939.

TAVARES, Luís Henrique Dias. Comércio Proibido de Escravos. São Paulo: Ática, 1988. 